\title{
Cost analysis of a rainwater harvesting system in Poland
}

\author{
Grażyna Sakson ${ }^{1, *}$ \\ ${ }^{1}$ Institute of Environmental Engineering and Building Installations, Lodz University of Technology, \\ Poland
}

\begin{abstract}
Rainwater harvesting is an alternative water supply method that has become popular in recent years around the world. This is mainly due to financial reasons (reducing the cost of potable water and fees for rainwater discharge to the sewerage), but also because of environmental awareness. In Poland, rainwater harvesting systems are not often used because of their low financial viability determined by high system construction costs and the low prices of potable water. Earlier analysis conducted by the author showed that the payback period of investment outlays was from a dozen or so years for large buildings, to a few dozen for single-family houses. This situation may change after the introduction of common fees for discharging rainwater from impervious areas into sewerage, and fees for the reduction of natural retention on newly built-up areas, in accordance with new water regulations. This paper presents a cost analysis of rainwater harvesting systems for ten cities in Poland, with varying annual rainfall depth and various pricing for potable water. Analyses were carried out for a single-family house located in an area equipped with a municipal sewer system, and for a large building, located in an area equipped and not equipped with a municipal sewer system.
\end{abstract}

\section{Introduction}

The practice of rainwater collection and its reuse for some purposes has been known for a long time, but in the last 20 years rainwater harvesting $(\mathrm{RWH})$ systems are much more often implemented, mainly due to an increase in the price of tap water. In residential buildings, rainwater can replace $30-40 \%$ of tap water if it is used for flushing toilets. Saving drinking water can be greater when rainwater is used for garden irrigation, washing and for cleaning purposes. The profitability of using rainwater collection systems is very diverse not only in individual countries, but in their regions [1-5]. It depends primarily on the price of tap water, the annual rainfall depth, the characteristic of precipitations and the cost of RWH systems. The most expensive element of this system is the storage tank, so determining of its capacity is the basic condition for both the reliability of water supply and economic efficiency. As Campisano et al. [6] highlighted, the degree of RWH systems implementation and technology selection are not only strongly influenced by economic constraints, but also local regulations. HWR systems may not only decrease the demand of tap water, but also reduce

\footnotetext{
*Corresponding author: agrazyna.sakson-sysiak@p.lodz.pl
} 
the frequency, peaks and volumes of stormwater runoff into the sewer system which allows meeting drainage design criteria at new developments. The identification of RWH systems as a multi-functional technology and novel RWH system configuration results in rainwater storage tanks more often being installed in new buildings [6-7].

However, in Poland rainwater harvesting systems are not often used. Earlier analysis conducted by the author [8-9] for different buildings: single-family house, multi-family residential building and large building, showed that the payback period of the investment outlays was very high: from a dozen or so years for buildings with a large roof area to a few dozen for single-family houses. The calculations were based on the daily rainfall for Lodz from several years and confirm that RWH efficiency is usually higher in the case of large buildings, for example commercial, office, industrial and schools [10]. The results of other analyses for single-family house in Poland were similar [11].

\section{Cost/benefits analysis}

An analysis of RWH systems has been carried out for ten cities with varying annual rainfall depth in the last 20 years [12] and the price of tap water [13]. Their location is presented on the map of Poland (Fig. 1), where the average annual precipitation is shown.

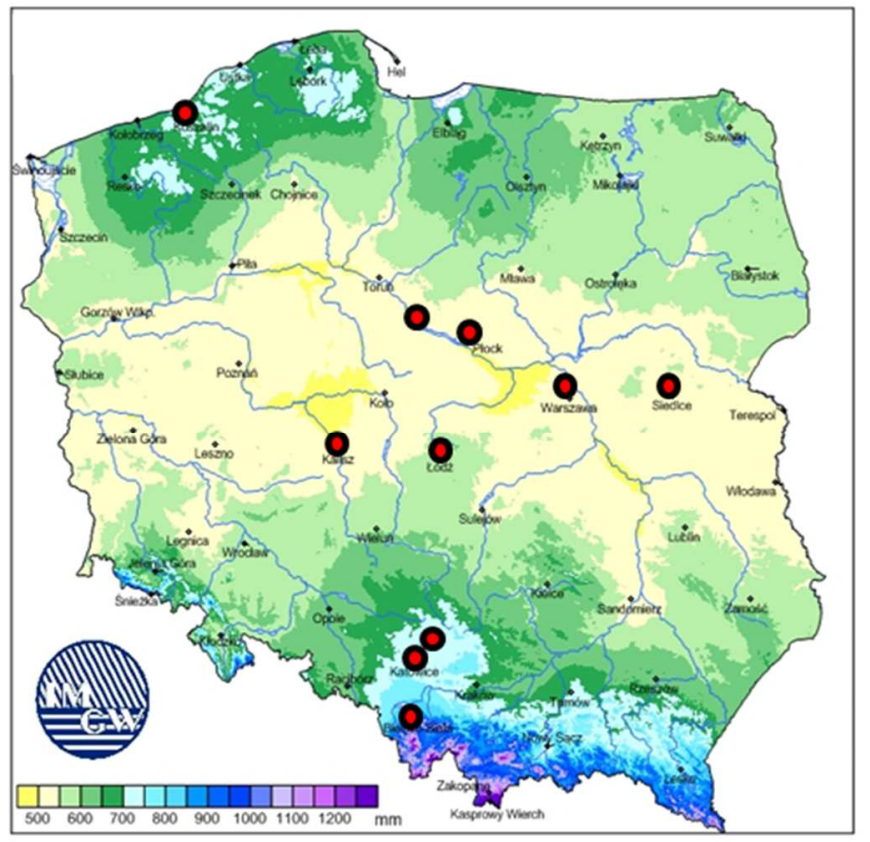

Fig. 1. Map of total annual precipitation in Poland [14] with the location of the studied cities.

The following three cases were considered:

a) Single-family house for 4 persons located in an area equipped with a municipal sewer system and a roof area of $125 \mathrm{~m}^{2}$, from which rainwater is collected. The rainwater will only be used for flushing the toilet. The daily demand is $150 \mathrm{l} /$ house.

b) Large building located in an area equipped with a municipal sewer system. The area of the building plot is $3500 \mathrm{~m}^{2}$ of which $70 \%$ is the roof of the building from which rainwater is collected. The daily demand for rainwater is $3 \mathrm{~m}^{3} /$ building.

c) New large building located in an area not equipped with a municipal sewer system. The other conditions are similar to those in b). 
In the case of a) and b) the rainwater discharged into a sewer system requires incurring fees according to the Water Law Act [15]. In the case of c) the fees result from the reduction of natural retention due to an increase in the imperviousness of the area. In all cases, it was assumed, that the use of rainwater storage facilities reduces charges according to Table 1.

Table 1. Fees for water services related to rainwater discharge according to the Water Law Act [15].

\begin{tabular}{|c|c|c|}
\hline Types of fees & $\begin{array}{c}\text { Discharge of } \\
\text { rainwater in an area } \\
\text { equipped with sewer } \\
\text { system }\end{array}$ & $\begin{array}{c}\text { Reduction of } \\
\text { natural retention in } \\
\text { an area not } \\
\text { equipped with sewer } \\
\text { system }\end{array}$ \\
\hline Fixed fee, & $5 \mathrm{PLN} /$ day for $1 \mathrm{~m}^{3} / \mathrm{s}$ & - \\
\hline Variable fee & $1,50 \mathrm{PLN} / \mathrm{m}^{3}$ year & $1,00 \mathrm{PLN} / \mathrm{m}^{2}$ year \\
\hline - without rainwater detention & $1,25 \mathrm{PLN} / \mathrm{m}^{3}$ year & $0,60 \mathrm{PLN} / \mathrm{m}^{2}$ year \\
\hline - retention $<10 \%$ of annual rainfall outflow & $1,00 \mathrm{PLN} / \mathrm{m}^{3}$ year & \multirow{2}{*}{$0.30 \mathrm{PLN} / \mathrm{m}^{2}$ year } \\
\hline - retention $>10 \%$ of annual rainfall outflow & $0,75 \mathrm{PLN} / \mathrm{m}^{3}$ year & \\
\hline - retention $>20 \%$ of annual rainfall outflow & $0,15 \mathrm{PLN} / \mathrm{m}^{3}$ year & $0.10 \mathrm{PLN} / \mathrm{m}^{2}$ year \\
\hline - retention $>30 \%$ of annual rainfall outflow & &
\end{tabular}

The calculations were made with the following assumptions. The volume of the rainwater tank is min. $10 \%$ of the annual volume of rainwater discharged from the roof of the building. This allows a reduction of fees by PLN 0.50 for $a$ ) and b), and by PLN 0.70 for c). It was also assumed that the water demand for flushing toilets is fully covered by rainwater, which is possible only in some years, with favorable rainfall characteristics. As the previous analysis showed [9], although the total volume of rainwater collected from roofs is greater than the annual demand, during long periods of dry weather, the tank must be refilled with tap water. The basis for assessing the profitability of the investment was the payback period (PBP) of investment costs. It was calculated on the basis of unit price of $1 \mathrm{~m}^{3}$ of tank and the annual economic benefits resulting from the reduction of fees for potable water as well as fees for discharging rainwater into sewage systems or fees for reducing natural retention. The calculations were carried out for the variant with no fees for draining rainwater (1) and with fees (2), so the formula to calculate the payback period was as follows:

$$
P B P 1=\frac{V \times T U C}{R D \times W P}
$$

or

$$
P B P 2=\frac{V \times T U C}{R D \times W P+R F R}
$$

PBP - payback period [years]

$\mathrm{V}$ - storage tank volume $\left[\mathrm{m}^{3}\right]$

TUC - unit cost of tank: $2000 \mathrm{PLN} / \mathrm{m}^{3}$ for a plastic tank in a single-family house,

$\mathrm{RD}$ - annual rainwater demand $\left[\mathrm{m}^{3}\right]$

$1.200 \mathrm{PLN} / \mathrm{m}^{3}$ for a concrete tank in a large building

WP - price of $1 \mathrm{~m}^{3}$ of potable water [PLN]

RFR - reduction of fees for rainwater discharged into sewerage (the volume of rainwater discharged from the roof $\times$ reduction of the unit fee according to Table 1 ) or fees for the reduction of natural retention (area of roof $\times$ reduction of the unit fee according to Table 1 ).

\section{Results and discussion}

The calculation of the results for a single-family house equipped with a tank of a volume equal to $10 \%$ of the annual rainwater runoff from the roof are shown in Table 2 . As can be 
seen, the payback period is very high, from 41 to 94 years depending on the annual rainfall and tap water price. Including the discount of fees for rainwater discharged into municipal sewer system lowered the PBP by 4 to 18 years, but it was still high, and not at an acceptable level. The PBP was higher in the case of a higher annual rainfall, but in such cases the tank was larger, and thus the investment costs were also higher.

Table 2. PBP for RWH system in a single-family house for different locations (tank with a volume of $10 \%$ of rainwater runoff).

\begin{tabular}{|c|c|c|c|c|c|c|c|c|}
\hline Location & $\begin{array}{c}\text { Annual } \\
\text { rainfall } \\
(\mathrm{mm})\end{array}$ & $\begin{array}{c}\text { Potable } \\
\text { water } \\
\text { price } \\
(\text { PLN/m } \\
\text { ) }\end{array}$ & $\begin{array}{c}\text { Tank } \\
\text { volume } \\
\left(\mathbf{m}^{3}\right)\end{array}$ & $\begin{array}{c}\text { Cost } \\
\text { (thous } \\
\text { PLN) }\end{array}$ & $\begin{array}{c}\text { Annual } \\
\text { savings - } \\
\text { potable } \\
\text { water } \\
\text { (PLN) }\end{array}$ & $\begin{array}{l}\text { PBP1 } \\
\text { (year) }\end{array}$ & $\begin{array}{c}\text { Annual } \\
\text { savings - } \\
\text { fees for } \\
\text { rainwater } \\
\text { discharges } \\
\text { (PLN) }\end{array}$ & $\begin{array}{l}\text { PBP2 } \\
\text { (year) }\end{array}$ \\
\hline $\begin{array}{l}\text { Bielsko- } \\
\text { Biała }\end{array}$ & 797 & 4,67 & 10,0 & 19,9 & 256 & 78 & 50 & 65 \\
\hline $\begin{array}{l}\text { Dąbrowa } \\
\text { Górnicza }\end{array}$ & 671 & 7,41 & 8,4 & 16,8 & 406 & 41 & 42 & 37 \\
\hline Kalisz & 493 & 2,99 & 6,2 & 12,3 & 164 & 75 & 31 & 63 \\
\hline Katowice & 566 & 5,82 & 7,1 & 14,2 & 319 & 44 & 35 & 40 \\
\hline Koszalin & 738 & 3,57 & 9,2 & 18,5 & 195 & 94 & 46 & 76 \\
\hline Łódź & 577 & 4,18 & 7,2 & 14,4 & 229 & 63 & 36 & 54 \\
\hline Płock & 376 & 4,49 & 4,7 & 9,4 & $211 *$ & 45 & 24 & 40 \\
\hline Siedlce & 625 & 3,53 & 7,8 & 15,6 & 193 & 81 & 39 & 67 \\
\hline Warszawa & 543 & 4,54 & 6,8 & 13,6 & 249 & 55 & 34 & 48 \\
\hline Włocławek & 526 & 2,94 & 6,6 & 13,2 & 161 & 82 & 33 & 68 \\
\hline
\end{tabular}

*- calculations based on the volume of rainwater collected from the roof, because the rainwater demand is greater

The cost-effectiveness of RWH systems strongly and primarily depends on the price of tap water, as well as on the annual rainfall, particurarly when the volume of the tank has been set to provide $10 \%$ retention of rainwater (Fig. 2 and Fig. 3). In the analyzed cases, the tank volume was generally too large in relation to the rainwater demand and the roof surface from which the rainwater is collected. The optimal volume of the storage tank for a single-family home is about $5 \mathrm{~m}^{3}$. In a simplified way, the tank volume can be set, e.g. with the assumption of $1 \mathrm{~m}^{3}$ for 1 person or $1 \mathrm{~m}^{3}$ for a $25 \mathrm{~m}^{2}$ roof from which the rainwater is collected [9].

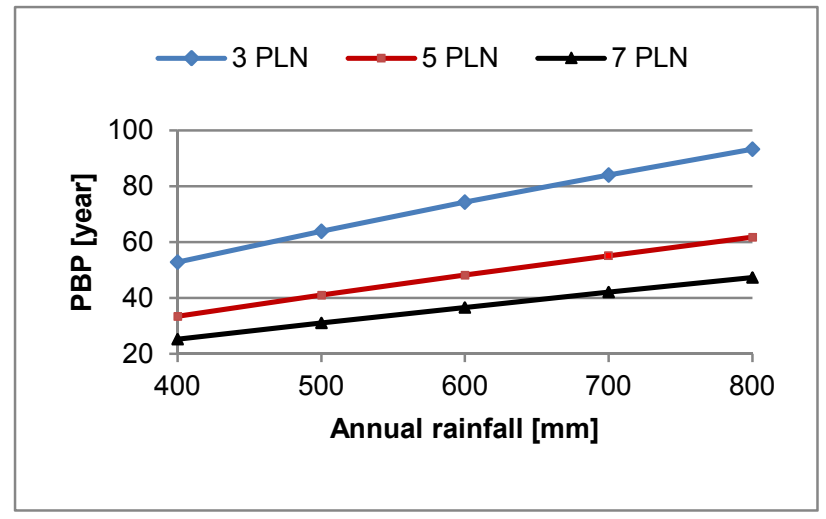

Fig. 2. PBP for a RWH system in a single-family house depending on the annual rainfall for the different prices of potable water (tank with a volume of $10 \%$ of annual discharge). 


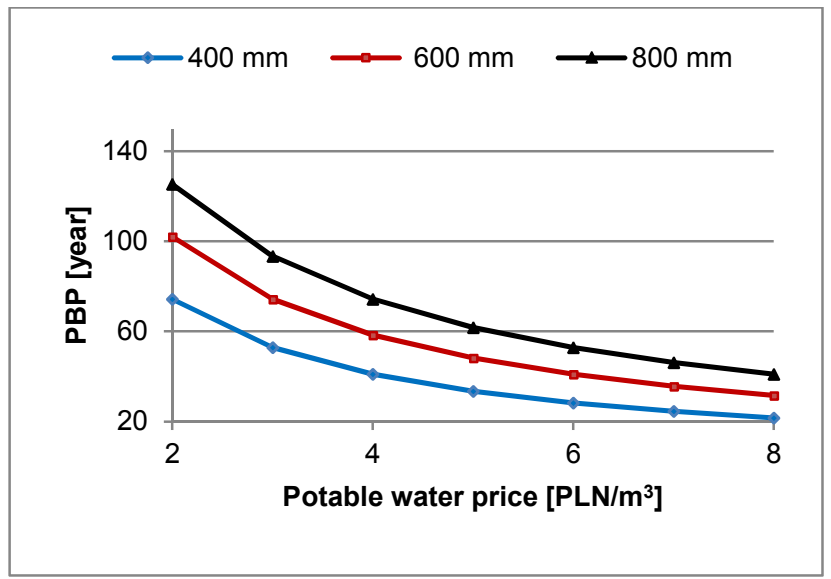

Fig. 3. The PBP for a RWH system in a single-family house depending on the price for $1 \mathrm{~m}^{3}$ of potable water for different annual rainfall (tank with a volume of $10 \%$ of annual discharge).

In the case of a large building, the PBP is much shorter but still high: from 24 to 56 years and can be reduced by 2-11 years if the fees for draining rainwater into the sewerage system are reduced, or by 4-17 years if the fees for reduction of natural retention are reduced (Table 3 ). The rainwater storage tanks do not allow the recovery of natural retention reduced due to the sealing of the surface, so it is not certain that, according to the Water Law [15], their use will allow a reduction in fees. If this is the case, the PBP may be shorter than 20 years in some cities.

Table 3. The PBP for a RWH system in a large building for different locations (tank with a volume of $10 \%$ of rainwater runoff).

\begin{tabular}{|l|c|c|c|c|c|c|c|c|}
\hline Location & $\begin{array}{c}\text { Tank } \\
\text { volume } \\
\left(\mathbf{m}^{\mathbf{3}}\right)\end{array}$ & $\begin{array}{c}\text { Cost } \\
\text { (thous } \\
\text { PLN) }\end{array}$ & $\begin{array}{c}\text { Annual } \\
\text { savings - } \\
\text { potable } \\
\text { water } \\
\text { (PLN) }\end{array}$ & $\begin{array}{c}\text { PBP1 } \\
\text { (year) }\end{array}$ & $\begin{array}{c}\text { Annual } \\
\text { savings - } \\
\text { fees for } \\
\text { rainwater } \\
\text { discharges } \\
\text { (PLN) }\end{array}$ & $\begin{array}{c}\text { Annual } \\
\text { PBP2 } \\
\text { (year) } \\
\text { fees for } \\
\text { reduction } \\
\text { of natural } \\
\text { retention } \\
\text { (PLN) }\end{array}$ & $\begin{array}{c}\text { PBP2 } \\
\text { (year) }\end{array}$ \\
\hline Bielsko-Biała & 195 & 234 & 5114 & 46 & 976 & 38 & 1715 & 34 \\
\hline $\begin{array}{l}\text { Dąbrowa } \\
\text { Górnicza }\end{array}$ & 164 & 197 & 8114 & 24 & 822 & 22 & 1715 & 20 \\
\hline Kalisz & 121 & 145 & 3274 & 44 & 604 & 37 & 1715 & 29 \\
\hline Katowice & 139 & 166 & 6373 & 26 & 693 & 24 & 1715 & 21 \\
\hline Koszalin & 181 & 217 & 3909 & 56 & 904 & 45 & 1715 & 39 \\
\hline Lódź & 141 & 170 & 4577 & 37 & 707 & 32 & 1715 & 27 \\
\hline Płock & 92 & 111 & $4135^{*}$ & 27 & 461 & 24 & 1715 & 19 \\
\hline Siedlce & 153 & 184 & 3865 & 48 & 766 & 40 & 1715 & 33 \\
\hline Warszawa & 133 & 160 & 4971 & 32 & 665 & 28 & 1715 & 24 \\
\hline Włocławek & 129 & 155 & 3219 & 48 & 644 & 40 & 1715 & 31 \\
\hline
\end{tabular}

*- calculations based on the volume of rainwater collected from the roof, because the rainwater demand is greater

The presented data prove the low profitability of using rainwater harvesting systems to ensure rainwater retention at $10 \%$ of the annual rainwater runoff. Therefore, the next step was the economic evaluation of RWH systems in a situation where the volume of the tank is optimal, taking into account rainwater demand. It was assumed that the capacity of the tank is $5 \mathrm{~m}^{3}$ in a single-family house and $50 \mathrm{~m}^{3}$ in a large building. As can be seen from Table 4, the PBP for a single-family house in such a case is still very high, but the benefits of reducing the fees for rainwater discharging into sewer systems can shorten the PBP by even 10 years. 
Table 4. The PBP for RWH with an optimal volume for the tank in a single-family house and in a large building for different locations.

\begin{tabular}{|c|c|c|c|c|c|c|c|}
\hline \multirow[b]{2}{*}{ Location } & \multicolumn{3}{|c|}{ Single family house } & \multicolumn{4}{|c|}{ Large building } \\
\hline & $\begin{array}{c}\text { Tank } \\
\text { volume } \\
\left(\mathbf{m}^{3}\right)\end{array}$ & $\begin{array}{c}\text { PBP - } \\
\text { saving } \\
\text { potable } \\
\text { water } \\
\text { (year) }\end{array}$ & $\begin{array}{l}\text { PBP saving } \\
\text { potable } \\
\text { water+ } \\
\text { fees for } \\
\text { rainwater } \\
\text { (year) }\end{array}$ & $\begin{array}{c}\text { Tank } \\
\text { volume } \\
\left(\mathbf{m}^{3}\right)\end{array}$ & $\begin{array}{c}\text { PBP - } \\
\text { saving } \\
\text { potable } \\
\text { water } \\
\text { (year) }\end{array}$ & $\begin{array}{c}\text { PBP } \\
\text { saving } \\
\text { potable } \\
\text { water+ } \\
\text { fees for } \\
\text { rainwater } \\
\text { (year) }\end{array}$ & $\begin{array}{c}\text { PBP } \\
\text { saving } \\
\text { potable } \\
\text { water+ } \\
\text { fees for } \\
\text { reduction } \\
\text { of } \\
\text { retention } \\
\text { (year) }\end{array}$ \\
\hline Bielsko-Biała & 5 & 39 & 33 & 50 & 12 & 11 & 10 \\
\hline $\begin{array}{l}\text { Dąbrowa } \\
\text { Górnicza }\end{array}$ & 5 & 25 & 22 & 50 & 7 & 7 & 7 \\
\hline Kalisz & 5 & 61 & 51 & 50 & 18 & 17 & 14 \\
\hline Katowice & 5 & 31 & 28 & 50 & 9 & 9 & 8 \\
\hline Koszalin & 5 & 51 & 41 & 50 & 15 & 14 & 12 \\
\hline Łódź & 5 & 44 & 38 & 50 & 13 & 12 & 11 \\
\hline Płock & 5 & $47 *$ & 43 & 50 & $15^{*}$ & 14 & 12 \\
\hline Siedlce & 5 & 52 & 43 & 50 & 16 & 14 & 12 \\
\hline Warszawa & 5 & 40 & 35 & 50 & 12 & 11 & 10 \\
\hline Włocławek & 5 & 62 & 52 & 50 & 19 & 17 & 14 \\
\hline
\end{tabular}

*- calculations based on the volume of rainwater collected from the roof, because the rainwater demand is greater

The use of rainwater harvesting systems in large buildings is more cost-effective. In the case of a tank volume adapted to the roof surface and water demand, the potable water savings allow the return of investment outlays after 7-19 years. The benefits of lowering fees for water services are not significant, because the capacity of the tank is less than $10 \%$ of the annual outflow volume of rainwater. In some cities a reduction in fees does not reduce the PBP (years) at all.

In large-area buildings rainwater can be used for various purposes, not only for the flushing of toilets, but also for cleaning, for washing vehicles, etc. The economically optimal roof surface, from which rainwater is collected in $\mathrm{m}^{2}$ was estimated by Vaes and Berlamiont at $75-100 \%$ of their consumption expressed in 1/d [16]. Fig. 4 shows the dependence of PBP on the rainwater demand in a large building at various prices of potable water. As can be seen, the PBP can be achieved in less than 10 years when the price of tap water is above 5 $\mathrm{PLN} / \mathrm{m}^{3}$ and the rainwater demand is greater than $3 \mathrm{~m}^{3} /$ day, so the roof surface in $\mathrm{m}^{2}$ makes up over $80 \%$ of rainwater consumption expressed in $1 / \mathrm{d}$. The impact of the reduction of fees for rainwater discharge into the sewer system is not significant. 


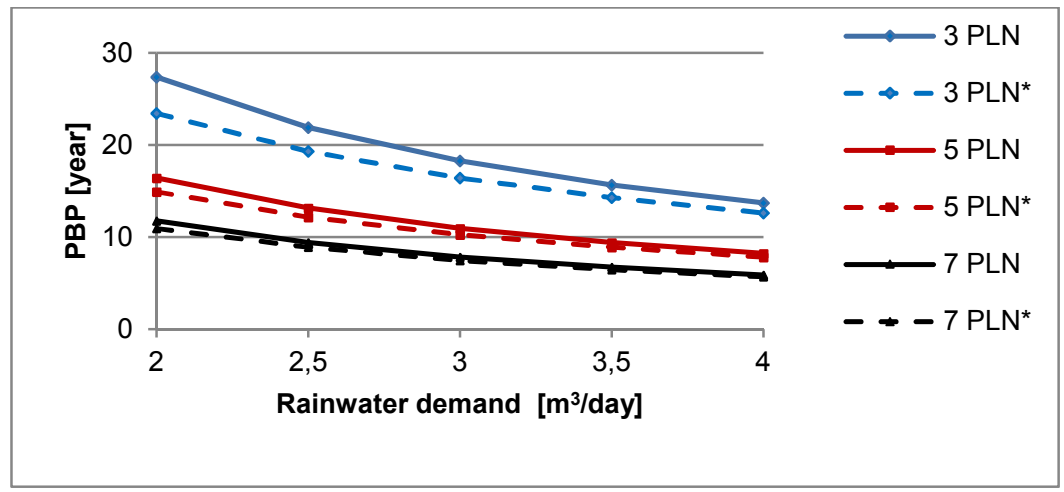

Fig. 4. The PBP for a RWH system in a large building depending on the daily rainwater demand for different prices of potable water $(*$ including a discount in fees for rainwater discharge).

Of course, the results of the conducted analyses are significantly influenced by the assumed unit price of the storage tank, which is higher in the case of a smaller tank in a single-family house, and lower for a larger tank in a large building. The prices may be different, hence the results of the calculations are indicative. However, the analyses clearly indicate that in the case of single-family houses, rainwater harvesting systems are still not profitable, and the new system of fees, introduced by the Water Law [15] does not significantly improve their economic efficiency, so there will be no additional incentive to apply them. Therefore, other solutions are necessary, e.g. a system of subsidies for investors or greater discounts in fees. In the case of large builgings the profitability of using rainwater harvesting systems is higher, but it mainly results from the savings of potable water, and the reduction of fees resulting from the introduction of retention, is sometimes negligibly small. However, it should be noticed that the final cost-efficiency depends on the price of tap water and the depth of precipitation in a given town. Rainfall characteristics are also very important, so especially in the case of large buildings, the efficiency and reliability of these systems should be analyzed based on data on the daily rainfall from a minimum of several years. The depth of precipitation in Poland may vary by up to several dozen percent in particular years, and there may also be different periods of dry weather between precipitation. These factors have a significant impact on the efficiency of the systems [1, 5, 7-9]. In our climate, in the winter, there may be longer breaks in the rainwater tank supply, which will reduce the efficiency of the system. The wider range of rainfall data allows a more reliable financial evaluation of rainwater harvesting systems.

\section{Conclusions}

The financial evaluation of rainwater harvesting systems conducted for ten cities in Poland have shown varying results, but in each city the payback period was high, particurarly in the case of single-family house. The introduction of a new system of fees and discounts anticipated in the new Water Law Act will not be a significant incentive for potential investors. In the case of these systems, other benefits should be taken into account: a reduction in annual stormwater discharge into sewerage, a reduction of stormwater flow during an extreme event, rainwater reuse and more sustainable water management, so it is necessary to develope additional solutions supporting their implementation. 


\section{References}

1. Ch. Amos, A. Rahman, J. Mwangi Gathenya J Clean Prod 172 196-207 (2018)

2. R. Farrenya, X. Gabarrell, J. Rieradevall, Resour Conserv Recycl, 55, 686-694 (2011)

3. A. Gires, B.de Gouvello, Wat Sci Technol 60, 3, 543-553 (2009)

4. E. Hajani, A. Rahman Water, 6, 945-960 (2014)

5. L. Liuzzo, V. Notaro, G. Freni, Water 8, 18 (2016)

6. A.Campisano, D. Butler, S. Ward, M.J. Burns, E. Friedler, K. DeBusk, L.N. Fisher-Jeffes, E. Ghisi, A. Rahman, H. Furumai, M. Han , Water Res 115, 195-209 (2017)

7. P. Melville-Shreeve, S. Ward, D. Butler, Water 8, 129-147 (2016)

8. G. Sakson, Monographs of Environ Eng Committee of Polish Academy of Sci 46,203-212 (2007)

9. G. Sakson, Rynek Instalacyjny 5, 35-38 (2010)

10. S. Ward, F.A. Memon, D. Butler, Water Res 46, 5127-5134 (2012)

11. D. Słyś, GWiTS, 3, 19-23 (2008)

12. https://www.weatheronline.pl

13. www.cena-wody.pl

14. www.imgw.pl

15. Water Law Act of 20 July 2017, Journal of Laws 2017, item 1566

16. G. Vaes, J, Berlamont, Wat Sci Tech, 39, 5, 57-64 (1999) 